\title{
EFFICIENCY OF SALE OF WINTER WHEAT GRAIN UNDER FORWARD CONTRACTS DEPENDING ON THE CONDITIONS OF THE MARKETING YEAR
}

\section{ЕФЕКТИВНІСТЬ ПРОДАЖУ ЗЕРНА ОЗИМОЇ ПШЕНИЦІ ЗА ФОРВАРДНИМИ КОНТРАКТАМИ ЗАЛЕЖНО ВІД УМОВ МАРКЕТИНГОВОГО РОКУ}

UDC 338.31:339.338.4:633.11

https://doi.org/10.32843/infrastruct45-17

\section{Kirpa Mykola}

Doctor of Agricultural Sciences, Professor, Deputy Director for Research SE The Institute of Grain Crops of National Academy

of Agrarian Sciences of Ukraine Kompaniets Viktoriya

Candidate of Economic Sciences, Senior Research Fellow,

Head of the Laboratory of Economics SE The Institute of Grain Crops of National Academy

of Agrarian Sciences of Ukraine Kulik Alla

Chief Specialist of the Laboratory of Economics

SE The Institute of Grain Crops of National Academy

of Agrarian Sciences of Ukraine
The article is devoted to the study of effectiveness of the sale of winter wheat grain under forward contracts in the conditions of 2020. The main legal and economic aspects of the implementation of state forward purchases of grain through PJSC "Agrarian Fund" and JSC "State Food and Grain Corporation of Ukraine" are considered. The flaws in the mechanism of forward purchases of grain, which reduce the interest of producers in this channel for the sale of grain products, as well as its importance as a means of state support, are revealed. Expenses of the production and sale of winter wheat grain under forward contracts in 2020 using the example of enterprises in the Dnipropetrovsk region are predicted. The costs associated with the conclusion of forward contracts, profit from the sale of winter wheat grain, as well as the level of profitability at the current price situation, which has developed during the period of mass harvesting, are calculated.

Key words: winter wheat, forward contracts, expenses, cost, profitability.

Статья посвящена исследованию эфрфективности реализации зерна озимой пше- ницы по форвардным контрактам в условиях 2020 года. Рассмотрены основные правовые и экономические аспекты осуществления государственных фрорвардных закупок зерна через ПАО «Аграрный фонд» и АO «Государственная продовольственнозерновая корпорация Украины». Выявлены недостатки в механизме фрорвардных закупок зерна, которые снижают интерес производителей к данному каналу сбыта зерновой продукции, а также его значение как средства государственной поддержки. Спрогнозированы затраты на производство и реализацию зерна озимой пшеницы по фрорвардным контрактам в 2020 роду на примере предприятий Днепропетровской области. Рассчитаны затраты, связанные с заключением фрорвардных договоров, прибыль от реализации зерна озимой пшеницы, а также уровень рентабельности в условиях текущей ценовой ситуации, которая сложилась в период массовой уборки урожая. Ключевые слова: озимая пшеница, фрорвардные контракты, затраты, себестоимость, рентабельность.

Розвиток зернової галузі має важливе значення для вирішення проблеми продовольчої безпеки, збільшення валютних надходжень, підвищення конкурентоспроможності вітчизняної продукції і в цілому - для відродження національної економіки нашої країни. В сучасних умовах підвищується значення протекційних заходів, які вживаються державою по відношенню до аграрного товаровиробника, а також застосування есективного механізму державного регулювання зернового ринку, одним з важелів якого є фрорвардні закупівлі зерна. Під час проведення дослідження були вивчені правові та економічні аспекти орорвардних програм, які пропонувалися ПАТ «Аграрний фронд» і АТ «Державна продовольчо-зернова корпорація України» в 2020 році. На основі результатів експериментальних досліджень Державної установи Інститут зернових культур Національної академії аграрних наук України та розроблених технологічних схем вирощування зернових і зернобобових культур розраховані нормативи витрат на виробництво зерна озимої пшениці залежно від рівня ресурсного забезпечення технології. На підставі вивчення відповідної інсрормаційної бази обгрунтований рівень витрат, пов'язаних з укладенням фрорвардних договорів, які стосуються підготовки значного пакету документів, укладення договорів страхування, договорів застави чи оформленням товарних (фрінансових) аграрних розписок, оплати нотаріальних послуг, сплати відсотків за користування коштами попередньої оплати тощо. Розраховано прогнозні витрати, пов'язані з реалізацією продукції, зокрема, ї̈ транспортуванням до місця зберігання. На підставі розрахунків загальної суми витрат визначено собівартість продукції, що реалізується в рахунок виконання фрорвардного контракту, суму доплати, скориговану на зміну курсу долара США, прибуток від реалізації в розрахунку на тонну продукції, рівень рентабельності та беззбитковий рівень врожайності озимої пшениці залежно від рівня ресурсного забезпечення технології, відсоткової ставки за користування коштами попередньої оплати і якісних показників зерна, що визначають рівень ціни реалізації.

Ключові слова: озима пшениця, форвардні контракти, витрати, собівартість, рентабельність.

Problem statement. In the current conditions of raising global socio-economic crisis, importance of the policy of state protectionism in relation to the agricultural sector, in particular, the production of grain, is increasing. It is known that development of the grain sector is a strategically important task, since the level of food security of the state, the formation of its export potential and the creation of opportunities for sustainable development of the country's economy, its regions and agricultural enterprises depend on its successful operation.

In the context of improving the efficiency of grain production, an important direction of state activity is formation and development of an organized grain market and its infrastructure, as well as the use of a set of levers for its regulation, one of which is forward grain purchases.
Analysis of recent research and publications. Problems of state regulation of agricultural markets were dealt with by T. AndrosovHch[1], V. Pmyrwa, H. Grigorieva [2], A. Gulei [3], M. Demianenko, A. Dibrova, S. Kvasha, Yu. Lupenko, M. Malik, L. Primostka, N. Reznik [3], P. Sabluk, M. Solodkyi, V. Feshchenko, V. Sheludko, O. Shpichak, B. Yazlyuk [3], O. Yatsuh [4] and others. Unfortunately, today, the policy of state regulation of the agricultural market and state protectionism remains imperfect. This concerns in particular to forward purchases of grain, the purpose of which is to form an intervention fund. It is intended, on the one hand, to ensure effective price regulation in the grain market, and on the other hand, to support domestic grain producers through a prepayment mechanism. Thus, there is a need to conduct the more profound analysis of the effectiveness of grain sales under forward contracts. 
Formulation of purposes of the article. The purpose of this article is to determine the efficiency of winter wheat grain sales under forward contracts in the conditions of the current marketing year.

Statement of the main research material. General tenets on the organization and conduct of forward purchases are regulated by the Economic Code of Ukraine, the laws of Ukraine "On Grain and Grain Market in Ukraine" dated July 04, 2002 and "On State Support for Agriculture of Ukraine" dated June 24, 2004, as well as by Resolution of the Cabinet of Ministers of Ukraine "On Introduction of State Forward Procurement of Grain" No. 736 dated May 16, 2007 [5].

Practical experience shows that the main subjects of forward contracts (or contracts for the supply of future harvest) today are, on the one hand, state-owned companies PJSC "Agrarian Fund" and JSC "SFGCU", and on the other hand, agricultural enterprises.

According to the "Procedure for forward state procurement of grain" approved by Resolution of the Cabinet of Ministers of Ukraine No. 736 dated May 16, 2007 [5], forward purchases include the procurement of grain of future harvest by PJSC "Agrarian Fund" from agricultural producers on the terms of advance payment of $50 \%$ of the value of grain, calculated on the basis of minimum intervention price at the time of conclusion of forward exchange contract.

The final settlement of the contract is based on the weighted average equilibrium (fixing) prices established during the last three trading sessions on the Agrarian Exchange and its certified accredited commodity exchanges at the time of procurement, less the weighted average interest on banks' loans granted for up to 12 calendar months, which are determined according to the data of National Bank of Ukraine.

Conclusion of the contract is carried out on the condition of the presence of an insurance contract for the case of loss or damage of future yield and/ or a standard contract for insurance of agricultural products (with state support) against agricultural production risks of complete annihilation of winter grain crops, concluded in according to provisions of legislation, and an original or certified copy of the payment order for payment of the insurance premium [5].

The price per unit of commodity and the total price of the grain procurement agreement are set in accordance with changes in market conditions at the time of actual fulfilment by the producer of its obligations to deliver a batch of grain to PJSC "Agrarian Fund" to the grain warehouse specified in the terms of the agreement within the established time frame (EXWGrain warehouse) [6]. Delivery of grain to the subject of its storage is carried out at the expense of the commodity producer [5].

The terms of the forward program for 2020 have provided the cooperation with producers for three types of pledge such as commodity agrarian receipt (120\% of the contract amount), financial agrarian receipt (120\% of the contract amount), and a pledge agreement for future harvest $(150 \%$ of the contract amount), which must be notarized. Funding has been provided by mineral fertilizers and money. The amount of advance payment has been determined by the decision of the Commission for Risks of PJSC "Agrarian Fund" up to 70-100 \%. The interest rate for using funds for USD has been set at $11 \%$.

The minimum purchase lots have amounted to 100 tons for wheat, 100 tons for maize, 100 tons for barley and 50 tons for rye. The purchase prices, based on which the prepayment has been made under contracts in 2020, have been amount of $4200 \mathrm{UAH} / \mathrm{t}$ for 2nd class wheat, $4000 \mathrm{UAH} / \mathrm{t}$ for 3rd class wheat, $3300 \mathrm{UAH} / \mathrm{t}$ for 3 rd class maize, $4000 \mathrm{UAH} / \mathrm{t}$ for $3 \mathrm{rd}$ class rye and $3300 \mathrm{UAH} / \mathrm{t}$ for 3rd class barley $[7 ; 8]$.

Direct purchases of grain of the future harvest (of wheat, barley, maize and rye) in 2020 have been carried out by JSC "SFGCU" in two stages through regional branches. During the first stage, there has been concluded a contract of procurement of grain crops of future harvest with producer, a notarized contract of pledge of future harvest or made official commodity agrarian receipts, and also the prepayment, which amounted to $3000 \mathrm{UAH}$ (including VAT) for one ton of wheat of 2 nd and 3rd classes, 3rd class barley, 3 rd class maize and 3300 UAH (including VAT) for one ton of rye grain of 1 st and 2 nd classes, has been conducted. The annual interest rate for the use of funds has been provided at the level of $9.5 \%-13.0 \%$ per annum, depending on the size of the grain lot and the basis of delivery. The insurance of future harvest has been an obligatory condition. The second stage of the Program has provided the delivery of grain by agricultural producers to grain warehouses (or elevators) in the terms specified in the contract and the final payment according to market prices for grain. The minimum size of lot has been set at the level of 100 tons [8; 9].

Under the contract terms, the amount of surcharge is determined on the basis of current market price (EXW, CPT) at the time of delivery less the amounts of advance payment, adjusted for changes in official USD exchange rate and accrued amounts for the use of funds according to the prescribed interest rate. The final payment is made in accordance with the actual sizes of grain supply [9].

Analysis of the terms of forward contracts has shown that the main function of assistance to the grain producer is to pay an advance payment (or supply mineral fertilizers) to ensure performance of works provided by technologies of growing grain crops. This condition is practically the only thing that can cause producer's interest in this form of contract. However, the study of the mechanism for concluding forward contracts has shown that there are many 
disadvantages that reduce their attractiveness for agricultural producers, even those who experience a funding deficit at the beginning of year. The main problematic aspects are:

1) an excessively compound procedure of conclusion of forward contracts, which requires the preparation of a significant set of documents and associated with this process administrative outlays and working time expenses;

2) obligatory conclusion of contracts of insurance of future harvest. For example, insurance of winter wheat for the spring-summer growing period in the conditions of the Dnipropetrovsk region provides for the application of insurance tariffs with a value from $3.7 \%$ to $15.8 \%$ and $3.4-11.1 \%$ for winter rye [10] depending on the level of yield and insurance coverage (0.50-0.70). In areas with more risky production conditions, the level of insurance tariffs is higher and reaches $16.2 \%$ in the Kherson and Chernivtsi regions when growing winter wheat and $16.9 \%$ in the Odesa region when growing winter rye [10].

3) obligatory registration of a commodity (or financial) agrarian receipt or a pledge agreement for the future harvest, which must be notarized at the expense of the producer. When notarizing agrarian receipts and pledge agreements, the statutory rate of state duty is $0.01 \%$ of the subject of pledge, but not less than five and not more than fifty non-taxable minimum incomes of citizens [11].

4) on the received amount of advance payment, which performs the main protective function, the agricultural producer must write out a tax invoice and pay VAT at the rate of $20 \%$;

5 ) in parallel, a fee is provided for the use of prepayment funds in accordance with the set interest rate $(11.0 \%$ in USD when there is concluding a contract with PJSC "Agrarian Fund" and 9.5-13.0\% for a contract with JSC "SFGCU").

Thus, it can be asserted that for today when a forward contract concludes, the agricultural producer has to incur excessively large expenses, which according to calculations [4] can reach to $15 \%$ of the amount of forward operations.

6) forward contracts of PJSC "Agrarian Fund" and JSC "SFGCU" are overloaded with the quantity and size of penalties for full or partial non-performance of conditions of grain delivery by volumes and terms.

For example, the contract with JSC "SFGCU" [9] for violation of the terms of payment provides a fee of a fine in the size of double NBU discount rate which effected at the time of late payment from the amount of overdue payment for each day of delay of obligations. The NBU's discount rate for 7 months of 2020 changed from $11.0 \%$ (31.01.2020) to $10.0 \%$ (from 13.03.2020), $8.0 \%$ (from 24.04.2020) and $6.0 \%$ (from 12.06.2020) [12]. On the other hand, in the case of full (or partial) non-performance of contract terms by the supplier (producer) he is obliged on the basis of a written request to return all previously transferred funds (or their relevant part), and also interest for using borrowed funds at the rate of $30 \%$ per annum for the period from the date of receipt of advance payment from JSC "SFGCU" until the day of its return and the penalty of $25 \%$ of the amount of the advance payment (or part thereof). It should be noted that as of July 22, 2020, the real rate for business development loans was 13.5-29.0\% with the average effective rate of $18.28 \%$ [13], which is significantly lower than the $30 \%$ rate. In a case of increasing the exchange rate of USD against UAH by more than $5 \%$ from the date of receipt of the prepayment to the day of its return, the supplier is obliged to pay exchange rate difference additionally.

In the case of grain delivery in violation of the term set by the conditions of the contract, the producer is obliged to pay to JSC "SFGCU" a penalty of $0.5 \%$ of the value of untimely delivered commodity for each day of delay. In a case of delay in delivery of grain within 30 calendar days, the supplier is obliged to make settlements with the buyer as in the case of complete (or partial) non-fulfillment of the contract.

The supplier bears full financial responsibility and, accordingly, pays all losses (including all penalties imposed by the controlling authorities on the buyer) and the buyer's lost profit for providing false information provided by the contract and documents submitted for its conclusion. The supplier is responsible for any breach of the contract, regardless of whether it is at fault.

If the supplier violates the terms of registration of tax invoice in the Unified State Register of Tax Invoices, he must pay a fine of $0.3 \%$ of the VAT amount specified in the tax invoice for each day of delay [9].

As of July 13, 2020 PJSC "Agrarian Fund" concluded forward contracts for the purchase of 95 thousand tons of grain, which is much less than last year [14]. In total, 540 contracts were signed and 1.8 million tons of grain crops were contracted during 2016-2019. The audit of the financial statements of PJSC "Agrarian Fund" found that in 2019 the total amount of losses of the company exceeded 3.27 billion UAH [15].

During 2020, JSC "SFGCU" has carried out purchases of food grain of three crops such as wheat, barley and maize. In particular, as of July 15, 2020, 67.2 thousand tons of wheat grain, 10.4 thousand tons of barley grain and 31.8 thousand tons of maize grain have been purchased. The total volume of purchases has been amount to 109.5 thousand tons [16].

Determination of the level of efficiency of winter wheat grain sale under forward contracts has been carried out on the example of the conditions of the Dnipropetrovsk region. First of all, the normative expenditures for growing this crop in the conditions of 
2020 have been calculated when it was placed in the crop rotation after unfallow predecessors (Table 1). Grounding norms of production expenses for cultivation winter wheat according to different technological schemes has been carried out on the basis of composed technological maps of cultivation, as well as using existing methodical recommendations. The calculations have been based on study of the experimental experience of SE The Institute of Grain Crops of NAAS and the developed technological schemes for four levels of resource saturation such as high, sufficient, satisfactory and low, the gradation of which was carried out taking into account the experience of scientific developments [17].

Calculations (Table 2) have been conducted on the example of the terms of the contract with JSC "SFGCU" using the purchase prices, which were offered by LLC "Kryvyi Rih Combine of Bread Products" [18] in condition of delivering product in a full size and making final settlements as of July 23,2020 , taking into account the exchange rate difference.

On the base of the foregoing information and methodical recommendations, the expenses related to conclusion of forward contracts and sales of product have been grounded. The payment for use of prepayment funds has been calculated for a period of 4.5 months. During conducting the research, the expenses calculations made for technologies with a low level of resource provision have not been taken into account, because on the one hand these technologies do not provide for the production of grain with high quality indicators, and on the other hand, the contract with JSC "SFGCU" clearly specifies the requirement for obligatory compliance with the technological regulation of grain crops cultivation.

The results of forecast calculations indicate that as of July 23, 2020 in the winter wheat grain market, there has been formed a rather favourable price situation, which, when in condition of immediately delivering grain after its harvesting to a grain warehouse (elevator), allows not only to cover the expenses connected with its growing, transporting to a storage place, insurance of the future harvest and other expenses associated with conclusion of forward agreements, but also to ensure a sufficient level of profitability, which, depending on the interest rate for use of prepayment funds, can amount to $25.3-26.4 \%$ for a satisfactory level of resource provision of technology (for the sale of 3rd class grain), 45.0-46.5 \% for a sufficient level (for the sale of 2nd class grain) and $42.7-44.2 \%$ (for the sale of 3rd class grain), and respectively $55.9-57.7 \%$ and 53.4-55.1 \% for a high level.

In this regard, it should be pointed out that there is a very small difference between the prices of 2nd and 3rd class grain, which obviously does not encourage a producer to increase investments of resources to obtain product with high quality indicators. The authors' calculations of the break-even level of winter wheat yield indicate that if the technology is used with a satisfactory level of resource provision, the producer should receive a minimum of 2.372-2.394 t/ha of grain with quality indicators of 3rd class, whereas when using intensive cultivation technologies, which provide for the introduction of powerful doses of mineral fertilizers and a set of measures to protect crops from pests, diseases and weeds, the

Table 1

Norms of expenses for winter wheat grain production depending on the level of resource provision of the technology, UAH/ha

\begin{tabular}{|l|c|c|c|c|}
\hline \multirow{2}{*}{\multicolumn{1}{|c|}{ Items of expenses }} & \multicolumn{3}{c|}{ Levels of resource provision of the technology and yield } \\
\cline { 2 - 5 } & $\begin{array}{c}\text { low } \\
\mathbf{1 . 8} \text { t/ha }\end{array}$ & $\begin{array}{c}\text { satisfactory } \\
\mathbf{3 . 0} \text { t/ha }\end{array}$ & $\begin{array}{c}\text { sufficient } \\
\mathbf{4 . 2} \text { t/ha }\end{array}$ & $\begin{array}{c}\text { high } \\
\mathbf{5 . 5} \text { t/ha }\end{array}$ \\
\hline Salary & 339.38 & 340.14 & 273.19 & 252.70 \\
\hline Unified social contribution & 74.66 & 74.83 & 60.10 & 55.59 \\
\hline Seeds & 773.03 & 1122.52 & 1262.31 & 1472.00 \\
\hline Fuel and lubricants & 849.69 & 923.55 & 952.60 & 795.50 \\
\hline Mineral fertilizers & 1056.90 & 2004.00 & 2725.38 & 3715.13 \\
\hline Plant protection means & 600.75 & 659.42 & 896.64 & 1030.81 \\
\hline Works and services & 142.36 & 225.91 & 627.42 & 809.73 \\
\hline Outlays on repair of non-current assets & 621.67 & 644.35 & 664.59 & 864.49 \\
\hline Amortization & 890.58 & 963.44 & 987.73 & 1291.07 \\
\hline $\begin{array}{l}\text { Other expenses for the maintenance of fixed } \\
\text { assets }\end{array}$ & 3.58 & 2.62 & 1.72 & 2.07 \\
\hline Other material expenses & 368.90 & 487.48 & 620.16 & 752.60 \\
\hline Rent of land plots or shares (units) & 907.53 & 907.53 & 907.53 & 907.53 \\
\hline Single tax & 287.38 & 287.38 & 287.38 & 287.38 \\
\hline Other manufacturing overheads & 223.10 & 299.87 & 373.20 & 449.90 \\
\hline In total & $\mathbf{7 1 4 0}$ & $\mathbf{8 9 4 3}$ & $\mathbf{1 0 6 4 0}$ & $\mathbf{1 2 6 8 7}$ \\
\hline
\end{tabular}


Forecast efficiency of winter wheat grain sales under forward contracts with JSC "SFGCU" in agricultural enterprises of the Dnipropetrovsk region in 2020

\begin{tabular}{|c|c|c|c|c|c|c|}
\hline \multirow{3}{*}{ Indicators } & \multicolumn{6}{|c|}{$\begin{array}{l}\text { Values of indicators depending on the sale price and the level } \\
\text { of interest rate for using prepayment funds }\end{array}$} \\
\hline & \multicolumn{3}{|c|}{$\begin{array}{c}5990 \text { UAH/t } \\
\text { (2nd class grain) }\end{array}$} & \multicolumn{3}{|c|}{$\begin{array}{l}5900 \text { UAH/t } \\
\text { (3rd class grain) }\end{array}$} \\
\hline & $9.5 \%$ & $11.0 \%$ & $13.0 \%$ & $9.5 \%$ & $11.0 \%$ & $13.0 \%$ \\
\hline $\begin{array}{l}\text { Expenses for insurance of future harvest, } \\
\text { registration of pledge agreements, commodity } \\
\text { agrarian receipts, notary services, payment of } \\
\text { interest for use of prepayment funds and other } \\
\text { expenses, UAH/t }\end{array}$ & 391.74 & 405.82 & 424.59 & 391.74 & 405.82 & 424.59 \\
\hline $\begin{array}{l}\text { including payment for use of } \\
\text { prepayment funds, UAH/t }\end{array}$ & 89.14 & 103.22 & 121.99 & 89.14 & 103.22 & 121.99 \\
\hline $\begin{array}{l}\text { Selling expenses (laboratory analysis of grain } \\
\text { quality, loading and unloading operations, } \\
\text { transportation of products, etc.), UAH/t }\end{array}$ & 272.70 & 272.70 & $272, .70$ & 272.70 & 272.70 & 272.70 \\
\hline \multicolumn{7}{|c|}{ Cost of sale of 1 ton of grain (depending on the level of resource provision of the technology), UAH } \\
\hline satisfactory & $\mathrm{x}$ & $\mathrm{x}$ & $\mathrm{x}$ & 3645.44 & 3659.52 & 3678.29 \\
\hline sufficient & 3197.78 & 3211.85 & 3230.62 & 3197.78 & 3211.85 & 3230.62 \\
\hline high & 2971.17 & 2985.25 & 3004.01 & 2971.17 & 2985.25 & 3004.01 \\
\hline Sale price excluding VAT, UAH/t & 4991.67 & 4991.67 & 4991.67 & 4916.67 & 4916.67 & 4916.67 \\
\hline Prepayment amount excluding VAT, UAH/t & 2500.00 & 2500.00 & 2500.00 & 2500.00 & 2500.00 & 2500.00 \\
\hline $\begin{array}{l}\text { The amount of the surcharge, adjusted for } \\
\text { changes in the exchange rate of the USD } \\
\text { (without excluding the payment for use of } \\
\text { prepayment funds), UAH/t }\end{array}$ & 2184.64 & 2184.64 & 2184.64 & 2109.64 & 2109.64 & 2109.64 \\
\hline Adjusted sale price, UAH/t & 4684.64 & 4684.64 & 4684.64 & 4609.64 & 4609.64 & 4609.64 \\
\hline \multicolumn{7}{|c|}{ Profit (depending on the level of resource provision of the technology), $\mathrm{UAH} / \mathrm{t}$} \\
\hline satisfactory & $\mathrm{x}$ & $\mathrm{x}$ & $\mathrm{x}$ & 964.20 & 950.12 & 931.36 \\
\hline sufficient & 1486.87 & 1472.79 & 1454.02 & 1411.87 & 1397.79 & 1379.02 \\
\hline high & 1713.47 & 1699.40 & 1680.63 & 1638.47 & 1624.40 & 1605.63 \\
\hline \multicolumn{7}{|c|}{ Profitability (depending on the level of resource provision of the technology), \% } \\
\hline satisfactory & $\mathrm{x}$ & $\mathrm{x}$ & $\mathrm{x}$ & 26.4 & 26.0 & 25.3 \\
\hline sufficient & 46.5 & 45.9 & 45.0 & 44.2 & 43.5 & 42.7 \\
\hline high & 57.7 & 56.9 & 55.9 & 55.1 & 54.4 & 53.4 \\
\hline \multicolumn{7}{|c|}{ Break-even yield level (depending on the level of resource provision of the technology), t/ha } \\
\hline satisfactory & $\mathrm{x}$ & $x$ & $x$ & 2.372 & 2.382 & 2.394 \\
\hline sufficient & 2.867 & 2.880 & 2.896 & 2.914 & 2.926 & 2.944 \\
\hline high & 3.88 & 3.505 & 3.527 & 3.545 & 3.562 & 3.584 \\
\hline
\end{tabular}

break-even threshold increases accordingly to the level of 3.488-3.527 when receiving 2 nd class grain and 3.545-3.584 t/ha when receiving 3rd class grain.

Therefore, it can be argued that the sale price, which has been formed at the beginning of the period of mass harvesting winter wheat, allows to ensure not only simple, but also expanded reproduction of production. However, it should be noted that in connection with the conclusion of forward agreements, producers must bear additional expenses, which, according to forecast calculations, amount to 391.74-424.59 UAH per 1 ton of product. It should also be noted that forward contracts are the most attractive for the producers who experience a shortage of financial, material and technical resources at the beginning of year, so interest in such contracts from resource ensured agricultural enterprises, which use high-intensity cultivation technologies, is highly improbable.

Due to the delay in the terms of harvesting grain and its delivery to a grain warehouse (elevator), appearance of the need to lead product to the proper quality indicators, the additional expenses, in particular, related to the accrual of interest for use of prepayment funds may significantly increase. On the other hand, from the point of optimistic forecasts relating winter wheat yield in 2019/2020 MY, it can expect a decrease in market prices in the future. This will naturally lead to a loss of profit and reducing efficiency of grain sale.

Conclusions. The results of the research show that today the state should play an important regulatory role, which would allow, on the one hand, through the formation of intervention funds and resources, as 
well as the establishment of economically reasonable prices for grain to stabilize grain supply sizes and reduce a range of price fluctuations during year, and on the other hand to ensure a guaranteed level of market prices for product, providing opportunities for grain producers to implement at least simple reproduction of production.

The study of the terms of the forward programs of PJSC "Agrarian Fund" and JSC "SFGCU" has shown that the procedure of concluding forward contracts is excessively compound and requires high expenses associated with the preparation of a significant set of documents, the conclusion of insurance contracts, pledge agreements or registration of commodity (financial) agrarian receipts, payment of notary services, payment of interest for the use of funds. According to forecast calculations, such expenses can amount to 391.74-424.59 UAH/t or higher. In addition, the contracts are overloaded with the quantity and size of penalties for full or partial non-compliance of conditions of grain delivery by volumes and terms.

At the time of mass harvesting winter wheat, the price established on the market as of July 23,2020 has been sufficient to ensure the profitability of wheat sale under forward contracts at the level of 25.3-26.4\% (for the sale of 3rd class grain) for a satisfactory level of resource provision of technology, 45.0-46.5\% (for the sale of 2nd class grain) and 42.7-44.2\% (for the sale of 3rd class grain) for a sufficient level, and respectively $55.9-57.7 \%$ and $53.4-55.1 \%$ for a high level, depending on the interest rate for the use of prepayment funds.

Due to the delay in the terms of harvesting grain and its delivery to a grain warehouse (elevator), appearance of the need to lead product to the proper quality indicators, the additional expenses may significantly increase. From the point of optimistic forecasts relating winter wheat yield in 2019/2020 MY, it can expect a decrease in market prices that may lead to a loss of profit and reducing efficiency of grain sale.

Further research will be conducted in the direction of finding ways to improve the mechanism of formation of intervention funds and resources and increase its protective effect for domestic agricultural producers.

\section{REFERENCES:}

1. Androsovych T. Yu. (2013) Mekhanizm derzhavnykh forvardnykh zakupivel zerna. [The mechanism of public forward procurement of grain]. Naukovyi visnyk NUBIP Ukrainy. Seriia "Ekonomika, ahrarnyi menedzhment, biznes", no. 181, part 4, pp. 38-44.

2. Grigorieva H. (2016) Pravovyi analiz forvardnykh zakupivel zerna yak zasobu derzhavnoi pidtrymky silskohospodarskykh pidpryiemstv [Legal analysis of forward purchases of grain as a means of state support of agricultural enterprises]. Pidpryiemnytstvo, hospodarstvo i pravo, no. 5, pp. 47-52.
3. Yazlyuk B. O., Gulei A. I., Reznik N. P. (2018) Suchasnyi stan ta problemy rozvytku birzhovoho rynku zerna $v$ Ukraini. [Current state and problems of development of the exchange grain market in Ukraine]. Ukrainskyi zhurnal prykladnoi ekonomiky, no. 4, vol. 3, pp. 8-13.

4. Yatsuh O. O. (2018) Otsinka diiuchoho mekhanizmu forvardnykh operatsii ta yoho analitychne zabezpechennia. [Estimation of the current mechanism of forward operations and its analytical support]. Derzhava ta rehiony, no. 2 (101), pp. 104-114.

5. Pro zaprovadzhennya derzhavnyh forvardnyh zakupivel zerna. Postanova Kabinetu Ministriv Ukrayiny [On introduction of state forward procurement of grain. Resolution of the Cabinet of Ministers of Ukraine ]. (2007). No. 736 dated 16 May 2007. Available at: https://zakon.rada.gov.ua/laws/show/736-2007\%D0\%BF\#Text (accessed 23 July 2020).

6 . Forvard-2020. Dohovir postavky zerna pshenytsi [Forward 2020.Wheat grain supply contract]. Available at: http://agrofond.gov.ua/buy/forvard-2020/ (accessed 23 July 2020).

7. PAT «Ahrarnyi fond» rozpochynaie forvardnu prohramu zakupivli zernovykh vrozhaiu 2020 roku [PJSC "Agrarian Fund" begins a forward program for the purchase of grain harvest in 2020]. Available at: http://agrofond.gov.ua/ news/list/795--pat-agrarnij-fondrozpochinaje-forvardnu-programu-zakupivli-zernovihvrozhaju-2020-roku/ (accessed 23 July 2020).

8. Forvardni zakupivli zerna vrozhaiu 2020 roku [Forward purchases of grain for the 2020 harvest]. Available at: https://www.rv.gov.ua/news/forvardni-zakupivlizerna-vrozhayu-u-2020-roci (accessed 23 July 2020).

9. Zakupivelni prohramy [Purchase programs]. Available at: https://www.pzcu.gov.ua/activity/zakupivelniprogramy/ (accessed 23 July 2020).

10. Standartni strakhovi taryfy dlia strakhuvannia maibutnoho vrozhaiu ozymykh zernovykh silskohospodarskykh kultur $z$ derzhavnoiu pidtrymkoiu vid silskohospodarskykh ryzykiv na vesniano-litnii period vyroshchuvannia. Zatverdzheni rozporiadzhenniam Natsionalnoi komisii, shcho zdiisniuie derzhavne rehuliuvannia u sferi rynkiv finansovykh posluh 07.04.2016 r. № 718 [Standard insurance rates for insurance of the future harvest of winter grain crops with state support from agricultural risks for the spring-summer period of cultivation. Approved by the order of the National Commission for State Regulation of Financial Services Markets on April 7, 2016 No. 718]. Available at: https://zakon.rada.gov.ua/ laws/show/z0650-16/print (accessed 23 July 2020).

11. Metodychni rekomendatsii na temu: "Ahrarni rozpysky" [Methodical recommendations on the topic: "Agrarian receipts"]. (2018). Dnipro: Holovne terytorialne upravlinnia yustytsii u Dnipropetrovskii oblasti. (in Ukrainian)

12. Oblikova stavka Natsionalnoho banku [Discount rate of the National Bank]. Available at: https://bank.gov.ua/ua/monetary/stages/archive-rish (accessed 23 July 2020).

13. Kredyty na rozvytok biznesu $v$ bankakh Ukrainy [Loans for business development in banks of Ukraine]. Available at: https://bankchart.com.ua/business/credit (accessed 23 July 2020).

14. V 2019/20 marketynhovomu rotsi «Ahrarnyi fond» zakontraktuvav za forvardnoiu prohramoiu 95 
tys. tonn zernovykh [In the 2019/20 marketing year, the Agrarian Fund contracted 95,000 tons of grain under the forward program]. Available at: http://agrofond.gov.ua/ news/list/886--v-201920-marketingovomu-roci-agrarnijfond-zakontraktuvav-za-forvardnoju-programoju-95-tistonn-zern// (accessed 23 July 2020).

15. Kompanii PAT «Ahrarnyi fond» bulo zavdano zbytkiv na sumu 3,27 mlrd hrn [PJSC Agrarian Fund suffered losses amounting to UAH 3.27 billion]. Available at: http://agrofond.gov.ua/news/list/805--kompaniji-patagrarnij-fond-bulo-zavdano-zbitkiv-na-sumu-327-mlrdgrn/?fbclid=IWAR1qgj1W0GdH1OCWnLIRZCSGLZD XIO51NyQv8ONMO_TcQxns-Zg93rOGpl (accessed 23 July 2020).
16. DPZKU v ramkakh forvardu profinansuvav ahrariiv na 328 mln hryven [JSK «SFGCU» financed farmers for 328 million UAH within the forward]. Available at: https://agravery.com/uk/posts/show/dpzku-vramkah-forvardu-profinansuvav-agrariiv-na-328-mlngriven (accessed 23 July 2020).

17. Sabluk P. T., Mazorenko D. I., Mazniev H. Ye. (2008) Tekhnolohii vyroshchuvannia zernovykh i tekhnichnykh kultur v umovakh Lisostepu Ukrainy [Technologies for growing cereals and industrial crops in the Forest-Steppe conditions of Ukraine]. Kyiv: NNTs IAE. (in Ukrainian)

18. Zakupivelni tsiny [Purchase prices]. Available at: https://www.pzcu.gov.ua/activity/zakupivelni-cziny/ (accessed 23 July 2020). 